\title{
REVISITING THE HISTORICAL NESTING RECORD OF THE WHOOPING CRANE AT BATTLEFORD, SASKATCHEWAN
}

Spencer G. Sealy

Department of Biological Sciences

University of Manitoba

Winnipeg, MB R3T 2N2

Spencer.Sealy@umanitoba.ca

Among the seven historical nest records of the Whooping Crane (Grus americana) that Robert Porter Allen listed from Saskatchewan in his monograph was one reported near my home town of Battleford, discovered in $1884 .{ }^{1}$ I recently examined the description of this and the other historical nesting records in Saskatchewan in the context of the proposal submitted to Canada Post prior to the issue of the first Whooping Crane stamp in 1955, and the photograph on which its design was inspired. ${ }^{2}$ Those nests have been listed by numerous authors ${ }^{3,4}$, but the evidence on which the Battleford record is based, in particular, is tenuous, and I re-examine it here.

The Battleford nest was documented entirely on the basis of second-hand information provided seven years after the fact by a man identified only as MacDonald to oologist Walter Raine, who reported it in his 1892 book Bird-Nesting in North-West Canada5:

MacDonald informed me he had seen a whooping crane flying towards the lake, and asked if I had seen any around there, which I had not. While at dinner he told me of a nest of the whooping crane he once found on the banks of the North Saskatchewan [River]; he said he remembered that nest well, as he and his brother came near losing their lives on the same day he found the nest. Seven years ago, just before the rebellion broke out amongst the NorthWest Indians, Mac. and his brother were camping near Battleford, on the North Saskatchewan, and were out on a tramp over the prairie, when they came across a nest of the whooping crane containing two eggs, which they left in the nest intending to call for them on their return (p. 82).

Further to this story, the two men ventured to the other side of the North Saskatchewan River in a canoe they found, but unfriendly people forced a quick retreat to their camp five miles away. Raine continued ( $p$. 84), "[o]n inquiring what became of the eggs of the whooping crane, Mac. told me that in their excitement they were forgotten, so were probably hatched. He described the nest as consisting of a flat mass of rushes and grass, about three feet in diameter." ${ }^{5}$

Although Allen rightly considered Raine's observations as "not very complete" (p. 177), he included the Battleford record as \#336 "(nesting, 2 eggs coll.)" in a comprehensive list of nest records and observations of the Whooping Crane that spanned the years 1722 to $1948 .{ }^{1}$ Assuming the nest and eggs were those of the Whooping Crane, Allen erred in reporting the eggs had been collected, as they clearly were not. According to today's standards of reporting, this record would have been considered at best hypothetical. But the record dates from more than 130 years ago, when conditions were much different, to which Raine frequently alluded in his narratives. Nevertheless, are we to assume Raine questioned MacDonald to confirm the identity of the cranes at the nest, if one or both adults were observed?
Other observers had misidentified Whooping Cranes around that time. ${ }^{6}$ Raine was experienced with cranes and their eggs ${ }^{7,8}$, but not all of it was positive. He purchased eggs of Little Brown Crane (Sandhill Crane (Antigone [formerly Grus] canadensis)) and compared their similar, albeit smaller, size with "... a series of twenty [Whooping Crane] eggs before me, which included sets from Manitoba and Montana." Sets of the Little Brown Crane, in particular, raised the ire of some ornithologists who accused him of deceptive practices and doubted the bird occurred in the region. ${ }^{9-11}$ Criticisms were later determined to be unfounded. ${ }^{12}$

Raine was a prodigious collector and dealer in birds' eggs, but some of his identifications were considered unreliable and his reputation suffered. ${ }^{12}$ Percy A. Taverner of the National Museum of Canada and ornithologists at the Royal Ontario Museum did not accept his egg collections. But C. Stuart Houston was not as quick to set aside all of Raine's records. He assessed them thoroughly and fairly and cited opinions expressed by important oologists of the day who defended his collections. Houston noted several instances where Raine's expertise proved useful in correcting misidentifications of egg sets made by other oologists. ${ }^{12}$ Many of Raine's photographs of nests and eggs were included in Reed's North American Birds Eggs, including one of the eggs of the Little Brown Crane taken in the Saltcoats Marshes, Saskatchewan, on 6 June $1901 .^{13}$ 
Raine's primary mistake seems to have been to rush prematurely to publication many of his observations and details of egg sets, particularly many of the early records reported in Bird-Nesting in North-West Canada - the sole source of information pertaining to the Whooping Crane nest near Battleford. But Houston rightly noted that errors in identification of some species were understandable in the early years of investigation of natural history, citing the dearth of suitable field guides as an example. Nevertheless, Houston considered many of Raine's records useful to the historian of natural history, if scrutinized carefully, especially by those familiar with the areas he visited. ${ }^{12}$

Raine was an engraver and watercolour artist based in Toronto (Figure 1). ${ }^{10,14}$ Although he visited the Prairie Provinces four times between 1891 and 1901'12, it was his normal practice to engage other individuals, generally local and often youthful residents, to collect nests and eggs for him. The skills of these collectors undoubtedly varied and, compounded with competition to discover nests of lesser known species, tended to feed people's doubts. The sparse details of the Whooping Crane nest near Battleford were provided by MacDonald, whom Raine met upon his arrival at Rush Lake, a railway siding just west of Herbert, Saskatchewan ${ }^{15}$, in early June, 1891. MacDonald was the station master there, and the two men became friends. Raine noted his "... newly made friend was a sportsman who had travelled all through the Saskatchewan region and understood the Indian language (p. 42)." ${ }^{5}$ Within a few days the two men were hunting Pronghorns (Antilocapra americana) together, an activity that Raine depicted in two

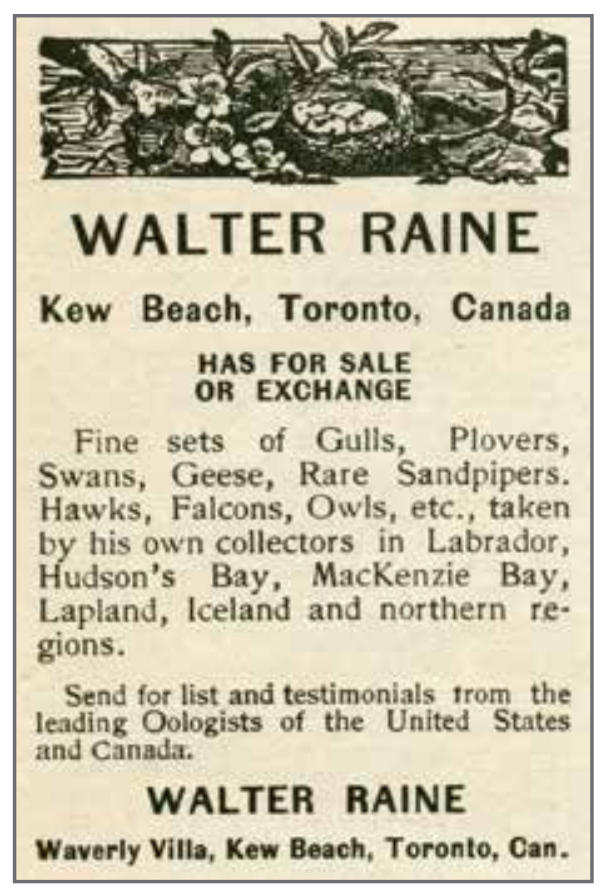

FIGURE 1: Egg sets for sale or exchange by Walter Raine, advertised in The Oologist, a monthly publication devoted to oology, ornithology and taxidermy.

plates facing page $50 .^{5}$

This was apparently Raine's only contact with MacDonald. During their conversations, MacDonald related his experience with the Whooping Crane nest at Battleford, seven years earlier. Raine probably would have described the nest and eggs in more detail, and the behaviour of the adults, had more information been available. To his credit, MacDonald's description of the nest as "... a flat mass of rushes and grass, about three feet in diameter", is generally consistent with descriptions of other early Whooping Crane nests. 3,4,15 Raine obviously judged MacDonald to be of good repute because he published his nest record. Credit for the most detailed description of the behaviour of adult Whooping Cranes attending an early nest rests with Neil Gilmore's observations in 1922, to which

A.C. Bent devoted two pages in the account of this species. ${ }^{16}$ Gilmore did not reveal the nest's location, but it was most likely at Shallow Lake, a few miles northwest of Kerrobert. ${ }^{3}$
Gilmore had been appointed Saskatchewan's first Game Guardian in 1907 and was sent by Fred Bradshaw to search for the remaining nests of the Whooping Crane. ${ }^{17}$ Bradshaw served as Saskatchewan's first Chief Game Guardian from 1912 to 1927 , and was director of the Provincial Museum from 1928 to $1935 .{ }^{18}$

The year of discovery of the Battleford nest has been given as 1884 , although recently as $1880^{4}$, possibly in error. Raine did not mention the year, but MacDonald told him the nest was discovered "just before the rebellion broke out amongst the North-West Indians." 5 That was $1885^{6}$, whereas the year before, i.e., "just before the rebellion", would have been 1884 — seven years prior to publication of Raine's book. This nest was recorded within the span of historic nest records ${ }^{3}$, but we will never know to what extent Whooping Cranes nested in the Battleford region, an area with extensive marshlands. ${ }^{19,20}$

Raine also reported nests of the Whooping Crane in Manitoba, including at least three from Oak Lake in the southwestern part of the province, 1891-1894, and possibly another nest in 1900, plus a fifth at Netley-Libau Marsh, north of Winnipeg in 1891. 1,5,21 The sketchy reports of those nests also were based on second-hand information, but at least three records were supported by egg sets purchased from collectors; some of those sets can be traced to museum collections. , $^{1,8}$

Other historical Whooping Crane nests may not stand up to rigorous scrutiny but, as Allen stated nearly 70 years ago (p. 24), "As unsatisfactorily as some few of these nesting records are, most of them constitute a valid picture of the former breeding of the species in Canada." 1 Preservation of 
those and other wetland habitats and restoration of historical water levels would be prudent if in an expanding population some Whooping Cranes choose to "return" to nest on the prairies.

\section{Acknowledgements}

Tim Novak responded to my inquiry about early photographs of Rush Lake held in the Saskatchewan Archives. I thank Daryl S. Henderson for carefully reading the manuscript and for pointing out a recent reference.

1. Allen RP (1952) The Whooping Crane. Research Report of the National Audubon Society, No. 3, New York.

2. Sealy SG (2020) William Rowan and Canada's $5 \not \subset$ Whooping Crane stamp: the proposal and the photograph. Blue Jay 78(3):19-26.

3. Hjertaas DG (1994) Summer and breeding records of the Whooping Crane in Saskatchewan. Blue Jay 52:99-115.

4. Johns BW (2019) Whooping Crane. Pages 222-225 in Birds of Saskatchewan (Smith AR, Houston CS, Roy JF, editors). Nature Saskatchewan, Regina.

5. Raine W (1892) Bird-nesting in NorthWest Canada. Hunter, Rose and Co., Toronto, ON.

6. Meyer D, Clipperton RC (2019) Whooping Cranes amid political turmoil, spring 1885. Blue Jay 77(2):40-41.

7. Raine W (1894) Bird nesting in Northwest Canada. Nidiologist 1:67-71.

8. Houston CS, Bechard MJ (1987) Early Manitoba oologists. Blue Jay 45:85-96.

9. Macoun J, Raine W (1896) Raine's crane case. Nidiologist 4:23-24.

10. Barnes RM (1910) Walter Raine. Oologist 27:125-126.

11. Raine W (1904) Discovery of the eggs of Solitary Sandpiper. Oologist 21:164-168.

12. Houston CS (1981) An assessment of Walter Raine and his Saskatchewan records. Blue Jay 39:168-181.

13. Reed CA (1904) North American Birds Eggs. Doubleday, Page \& Co., New York.
14. McNicholl MK, Cranmer-Byng JL, editors (1994) Ornithology in Ontario. Ontario Field Ornithologists, Special Publication, No. 1.

15. Barry B, editor (2005) Rush Lake. Page 366 in Geographic names of Saskatchewan. People Places Publishing, Regina; Rush Lake History Book Committee (1982) Excelsior Echoes, Derksen Printers, Steinbach, MB. The railroad was originally built through the municipality in 1882 to run north of Rush Lake, then a large body of water surrounded by emergent vegetation. After the C.P.R. drained the lake in 1905, the tracks were straightened to pass through the dry lake bed, and the Rush Lake siding was moved $3.2 \mathrm{~km}$ south to its current site. On 13 June 2019, I visited Rush Lake to envision what the area might have looked like nearly 130 years ago.

16. Bent AC (1963) Life histories of North American marshbirds. United States National Museum Bulletin, No.135, Washington, D.C.

17. Bradshaw F (1928) Report of the Provincial Museum of Natural History, Saskatchewan Department of Railways, Labour and Industries, pages 1-37.

18. Smith AR, Houston CS, Roy JF, editors (2019) Birds of Saskatchewan. Nature Saskatchewan, Regina.

19. Belcher M (1972) An early Provincial Museum field camp in the Battleford area. Blue Jay 30:8-17.

20. Austin JE, Hayes MA, Barzen JA (2019) Revisiting the historic distribution and habitats of the Whooping Crane. Pages 25-88 in Whooping Cranes: Biology and Conservation (French JB, Converse SJ, Austin JE, editors). Academic Press/Elsevier, New York.

21. Koes, R, Taylor P (2003) Whooping Crane. Pages 161-162 in The Birds of Manitoba, Manitoba Naturalists Society, Winnipeg.
POETRY

$$
\begin{gathered}
\text { Highway \#11 } \\
\text { (to Regina) } \\
\text { In his rich, heavy } \\
\text { winter coat }
\end{gathered}
$$

Coyote, at ease, his snout deep

in a frozen, ice-caked carcass.

Raven waits patiently.

His own winter plumage

fluffed out

body heat captured in

his glossy raiment

as he watches,

perched on a nearby

fence post.

This ancient tableau

goes on at its measured

pace,

framed by frantic, speeding vessels

of steel, glass and plastic

hurtling by

on four lanes of blacktop.

George Grassick

Box 205

Lumsden, SK

SOG 3 CO

ggrassick@sasktel.net 